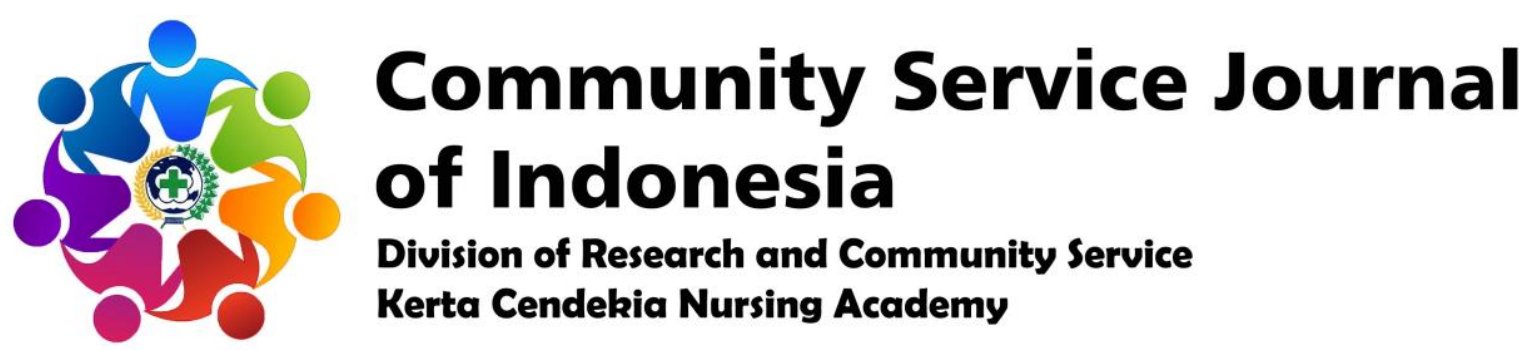

https://ejournal-kertacendekia.id/index.php/csji/index

Community Service Journal of Indonesia 1 (2) (2019): 31-33

Doi: https://doi.org/10.36720/csji.v1i2.136

\title{
DEPRESSION SYMPTOMS RECOGNITION "STOP SUICIDE" IN ADOLESCENTS
}

\author{
Faida Annisa ${ }^{1}$, Firdah Nur Hidayah ${ }^{2}$, Gilang Nova Permatasari ${ }^{2}$, Dominggus \\ Songupnuan $^{2}$, Dina Syafirah ${ }^{2}$, Putri Putu Rakman ${ }^{2}$, Rif'atul Umami ${ }^{2}$ \\ ${ }^{1}$ Lecturer of Kerta Cendekia Nursing Academy, Sidoarjo \\ ${ }^{2}$ Student of Kerta Cendekia Nursing Academy, Sidoarjo
}

\begin{abstract}
Health promotion activities on the Recognition of the Symptoms of Depression "Stop Suicide" in Junior High School of Al-Aziziyah is one form of community service in the form of counseling aimed at increasing students' knowledge about how to recognize depression symptoms which are frequent events that cause death. The implementation of these activities on November 27, 2019 took place at Junior High School of Al-Aziziyah, Kebonsari, Candi Sub-District, Sidoarjo. The target of this event was the students of Junior High School of AlAziziyah, Kebonsari, Candi Sub-District, Sidoarjo. Before the activity is carried out, there is a process of compiling the activity for approximately 3 weeks before the activity is carried out, starting from determining the theme of counseling to submitting permits to the parties concerned. As a form of evaluation, the activity was attended by 27 students and 1 teacher, participants participated in the activity happily and looked very enthusiastic, health promotion activities could run on time and smoothly.
\end{abstract}

Keywords: Depression symptoms, adolescent, health promotion.

\section{INTRODUCTION}

Depression is a condition that is described as a mood disorder that causes feelings of sadness and loss of interest that persists. Depression can affect your feelings, ways of thinking and behaving, and can make you have various emotional and physical problems. If the sadness lasts for a few days or weeks, interferes with work or other activities with family or friends, or is suicidal, this is likely depression. Discuss with your doctor if you feel symptoms of depression. Depression is a condition that often occurs in society. According to research, depression occurs in $80 \%$ of people at some time in their lives 
and can occur at any age. Depression is more common in women than men.

\section{OBJECTIVES}

General Purpose

After counseling by health promotion team, it is expected that the participants can understand the importance of the introduction of the symptoms of depression.

\section{Special Purpose}

After the health promotion, it is expected that the Junior High School of AlAziziyah, Kebonsari, Candi Sub-District, Sidoarjo can be:

1. Able to know the definition of depression.

2. Able to know the signs of depression.

3. Able to know the causes of depression.

4. Able to provide treatment for depression.

\section{PLAN OF ACTION}

Strategy Plan

The strategy plan implemented, including:

1. Coordinate with the principal of the Junior High School of Al-Aziziyah, Kebonsari, Candi Sub-District, Sidoarjo to request permission to carry out health education as a nursing program and help students of the Junior High School of Al-Aziziyah, Kebonsari, Candi Sub-District, Sidoarjo to gain useful knowledge.

2. Establish time contracts with students at the Junior High School of Al-Aziziyah, Kebonsari, Candi Sub-District, Sidoarjo.

3. Providing health education about Depression Symptoms Recognition "Stop Suicide".

\section{Implementation}

Actions taken in the implementation of these activities, including:

1. Contacted the principal of the Junior High School of Al-Aziziyah, Kebonsari, Candi Sub-District, Sidoarjo to request permission to carry out these activities and gathered students from the Junior High School of Al-Aziziyah, Kebonsari, Candi SubDistrict, Sidoarjo.

2. Prepare a place and counseling media.

3. Submission of health promotion materials about depression symptoms recognition "stop suicide" to students at the Junior High School of Al-Aziziyah, Kebonsari, Candi Sub-District, Sidoarjo.

Setting

This activity was carried out at the Junior High School of Al-Aziziyah, Kebonsari, Candi Sub-District, Sidoarjo.

Target

Target in this activity is all students of the Junior High School of Al-Aziziyah, Kebonsari, Candi Sub-District, Sidoarjo.

\section{RESULTS AND DISCUSSION}

The activity was carried out on Wednesday, November 27, 2019 at 08.10 West Indonesian Time in the Junior High School of Al-Aziziyah, Kebonsari, Candi Sub-District, Sidoarjo. The schedule does not match the planned schedule. Participants in counseling 27 students of the Junior High School of Al-Aziziyah, Kebonsari, Candi Sub-District, Sidoarjo. The teachers of the Junior High School of Al-Aziziyah, Kebonsari, Candi SubDistrict, Sidoarjo want to work together in implementing this health promotion activity. Participants who attended seemed 
enthusiastic and there were some who left the room before the event was over.

Equipment used during the counseling process are laptops, PowerPoints, videos, leaflets, LCD, X-Banners. Using simple language and sentences, the participants responded with enthusiasm. Questions asked by participants can be answered by all team members.

Based on the final evaluation conducted by the team, it was found that $90 \%$ of participants can understand the meaning of depression, $90 \%$ of participants can mention the symptoms of depression, $70 \%$ of participants can understand the causes of depression, $80 \%$ of participants can understand the handling of depression.

\section{CONCLUSION}

Improved knowledge of first aid in choke through health promotion was considered quite successful because $90 \%$ of participants can understand the meaning of depression, $90 \%$ of participants can mention the symptoms of depression, $70 \%$ of participants can understand the causes of depression, $80 \%$ of participants can understand the handling of depression.

\section{REFERENCES}

Kusumawati, F., \& Hartono, Y. (2010). Buku Ajar Keperawatan Jiwa. Jakarta: Salemba Medika

McNeely, C., \& Blanchard, J. (2010). The teen years explained: A guide to healthy adolescent development. Jayne Blanchard.

National Alliance on Mental Illness (NAMI). (2018). Managing Mental Health Condition-Teens.

Rachmadi, A. H. (2019). 5 dampak Negatif yang Dialami Korbn Bullying, Depresi hingga Bunuh Diri. Retrieved from https://akurat.co/gayahidup/id- 588772-read-5-dampak-negatif-yangdialami-korban-bullying-depresihingga-bunuh-diri on December 2, 2019.

Shabrina, A. (2018). 10 Penyebab Depresi yang paling Umum dan perlu Anda Ketahui. Retrieved from https://hellosehat.com/hidupsehat/fakta-unik/penyebab-depresiumum/ on November 10, 2019.

Tim CNN Indonesia. (2019). Kenali Gejala Depresi pada Diri Sendiri. Retrieved from https://www.cnnindonesia.com/gayahidup/20190626132011-255406575/kenali-gejala-depresi-padadiri-sendiri on November 10, 2019.

Tyas, A. (2012). Apa itu Bullying?. Retrieved from http://astrinityas.blogspot.com/2012/0 8/apa-itu-bullying.html on November 15, 2019. 